\title{
Seasonal variations of photosynthetic ciliates at a Mediterranean coastal site
}

\author{
M. Modigh* \\ Stazione Zoologica ‘A. Dohrn', Villa Comunale, 80121 Naples, Italy
}

\begin{abstract}
Standing stocks of ciliated protozoa were analyzed in weekly samples over 3 yr at a Mediterranean coastal site (Gulf of Naples, Tyrrhennian Sea). Photosynthetic ciliates contributed $49 \%$ of total ciliate biomass; heterotrophic naked choreotrichs and tintinnids contributed 25 and $16 \%$, respectively. The present paper focuses on the occurrence and succession of the autotrophic ciliate Mesodinium rubrum and of aloricate mixotrophic and heterotrophic choreotrichs. A very diverse assemblage of Strombidium spp. dominated the mixotrophic choreotrich populations, while Tontonia spp. contributed $14.3 \%$ and Laboea strobila $4.7 \%$ to plastidic ciliate abundance. The annual pattern of occurrence of these 3 genera of mixotrophic ciliates was similar over the 3 years of this study. Autotrophic and mixotrophic ciliates differed in the periods of maximum relative contribution to the ciliate assemblage. Mixotrophic choreotrichs dominated the ciliate populations in spring and summer while the maximum contribution of autotrophic ciliates occurred in winter. M. rubrum occurred in 2 forms - the larger form was the only Mesodinium observed in winter, while it was absent during summer, when the smaller Mesodinium was at times observed. The contribution of $M$. rubrum to annual primary production in the Gulf of Naples was about $3 \%$. Aloricate choreotrich populations were dominated by small cells; $92 \%$ of the aloricate heterotrophs were $<30 \mu \mathrm{m}$ equivalent spherical diameter (ESD), and for the mixotrophic ciliates $73 \%$ were $<30 \mu \mathrm{m}$ ESD and $24 \%$ were between 30 and $50 \mu \mathrm{m}$ ESD. Notwithstanding a very wide range of variation in aloricate choreotrich densities, 135 to 48800 cells $1^{-1}$, the relative contribution of different size classes was remarkably stable at any level of abundance. The calculated production for aloricate choreotrichs was between 2.3 and $3.3 \mathrm{~g}$ $\mathrm{C} \mathrm{m}^{-3} \mathrm{yr}^{-1}$ for the surface layer, about $50 \%$ of which was estimated to rely on ciliate grazing of bacterio- and picoplankton, as well as on photosynthesis covering, in part, the carbon demand of mixotrophic ciliates.
\end{abstract}

KEY WORDS: Planktonic ciliates $\cdot$ Mixotrophic choreotrichs $\cdot$ Mesodinium rubrum $\cdot$ Mediterranean coastal site

Resale or republication not permitted without written consent of the publisher

\section{INTRODUCTION}

Microzooplankton, dominated numerically by ciliated protozoa in most marine systems, forms an important link between the microbial food web and larger planktonic organisms (Sherr et al. 1986, Lynn \& Montagnes 1991, Verity 1991, Pierce \& Turner 1992). Ciliates display different trophic modes, from entirely autotrophic to mixotrophic and heterotrophic, thus

*E-mail: modigh@alpha.szn.it channeling energy and matter into the system from different sources. A consistent part of the aloricate choreotrichs is mixotrophic (Stoecker et al. 1987), as they capture chloroplasts from their prey and are able to gain part of their energy requirement from photosynthesis. Large parts of the Strombidiidae are plastidic and the mixotrophic ciliates are a permanent and rich assemblage in most aquatic systems (Stoecker et al. 1987, 1989, Laval-Peuto \& Rassoulzadegan 1988, Stoecker 1991, Dolan 1992). Through mixotrophy, plastidic ciliates may efficiently decrease the number of trophic transfers in planktonic food webs, and they 
can be extremely efficient producers of animal biomass in the oceans (McManus \& Fuhrman 1986).

The only autotrophic ciliate, Mesodinium rubrum (Lohmann) Hamburger and Buddenbrock, has long been ignored in studies on microzooplankton (Lindholm 1985) and phytoplankton (Crawford 1989). However, M. rubrum has been reported to be a frequent and abundant species in coastal areas (Lindholm 1985).

Photosynthetic ciliates provide only modest contributions to chlorophyll crop and primary production (Stoecker et al. 1989, 1991, Putt 1990). However, in areas where most of the phytoplankton is $<5 \mu \mathrm{m}$, i.e. not only the oligotrophic open ocean but also temperate seas during prolonged stratification (Banse 1995), photosynthetic ciliates may become disproportionately important in carbon flux to higher trophic levels (Dolan \& Marrasé 1995). Ciliates can also make an important contribution to chlorophyll and primary productivity in the $>20 \mu \mathrm{m}$ particle size, which is readily available for larger zooplankters (Sherr et al. 1986). Nonetheless, information on the different trophic groups of ciliates is scanty; thus the relative importance which they assume as consumers on pico- and phytoplankton, as well as potentially significant producers (Stoecker et al. 1987, Laval-Peuto \& Rassoulzadegan 1988, Putt 1990, Dolan \& Marrasé 1995), is poorly known.

In addition, most studies on pelagic ciliate assemblages use acid Lugol's solution as a fixative, which causes less distortion in the delicate ciliate morphotypes (Pierce \& Turner 1992). However, the coloration caused by this fixative prevents the possibility of identifying the fluorescence of kleptochloroplasts in the mixotrophic forms, and in several studies all ciliates, except the autotrophic Mesodinium rubrum, are considered heterotrophic (e.g. Smetacek 1981, Revelante \& Gilmartin 1987, Leakey et al. 1992, Nielsen \& Kiørboe 1994, Witek 1998, Coats \& Revelante 1999).

In fact, there are very few studies of full annual cycles of mixotrophic ciliate populations (Stoecker et al. 1987, Bernard \& Rassoulzadegan 1994); the first report for the Mediterranean Sea on mixotrophic choreotrich populations (Laval-Peuto \& Rassoulzadegan 1988) was carried out in the fall-winter period in the Bay of Villefranche. Information on the contribution of mixotrophic choreotrichs to the planktonic ciliate assemblage exists mainly on spatial distributions (Jonsson 1987, Stoecker et al. 1989, 1994b, 1996, Putt 1990, Suzuki et al. 1998, Perez et al. 2000), and the factors governing their relative abundance are unclear (Dolan 1992).

A study was thus implemented to investigate the succession of ciliate taxa and trophic groups and their relationships with ambient environmental conditions in a coastal area (Gulf of Naples, Tyrrhennian Sea) where additional information on the plankton compartment was available. A long-term ecological study was carried out at a site in the Gulf of Naples, Stn MC, located 2 miles off the coast on the 80-m isobath for physico-chemical and biological parameters (Scotto di Carlo et al. 1985). Information on phytoplankton and mesozooplankton populations has been available since 1984 (Mazzocchi \& Ribera d'Alcalá 1995, Zingone \& Sarno 2000), while for the microzooplankton community only a 1 year cycle, mainly focused on the tintinnid population, has been carried out (Scotto di Carlo et al. 1985). This paper reports on seasonal variations over $3 \mathrm{yr}$ at Stn MC of the autotrophic ciliate Mesodinium rubrum and of mixotrophic choreotrichs, providing data on aloricate heterotrophic choreotrichs for comparison. Trophic preferences of the ciliate population are also reflected by the size spectrum of the ciliates, and the relative contributions of different ciliate size classes were considered.

\section{MATERIALS AND METHODS}

Stn MC is influenced both by coastal waters and by the frequent flushing of oligotrophic Tyrrhennian waters, although no stable frontal structure has been observed in the Gulf of Naples between the 2 water masses (Carrada et al. 1980, Modigh et al. 1985). Precipitation mainly occurs in early spring and in late autumn, with an annual mean of $800 \mathrm{~mm} \mathrm{~m}^{-2} \mathrm{yr}^{-1}$; coastal waters expand out to the study site, as indicated by lower salinity values, after periods of rain. Low salinity values at Stn MC were associated with pulses of inorganic nutrients and phytoplankton biomass. Nitrate concentrations were generally below $0.2 \mu \mathrm{g}$-at $\mathrm{l}^{-1}$ except after periods of rain; phosphate concentrations were very low year round and often below the detection limit in summer.

The present study reports weekly microzooplankton samples $(\mathrm{N}=42)$ collected at $1 \mathrm{~m}$ at Stn MC from January 1997 till December 1999. Samples for chlorophyll and microzooplankton determinations were obtained with a CTD Niskin rosette sampler using 101 Niskin bottles. Chlorophyll measurements were made at -1 , $-2,-5,-10,-20,-40$ and $-60 \mathrm{~m}$. Chlorophyll a concentrations were measured spectrofluorimetrically on GF/F Whatman filters (Neveux \& Panouse 1987) for the whole period of sampling. From January 1998 till March 1999 chlorophyll a concentrations of phytoplankton size fractions were also measured by serial filtration on Nuclepore membranes of adequate pore size and the filtrate successively passed through GF/F filters. Chlorophyll fractions of $<10$ and $<2 \mu \mathrm{m}$ were determined; chlorophyll fractions of $>10$ and $>2$ to $<10 \mu \mathrm{m}$ were obtained by subtraction. 
Microzooplankton samples were collected from the $-1 \mathrm{~m}$ Niskin bottle; 21 were poured into a jar containing borate formalin (final concentration $2 \%$ ) and stored at $4^{\circ} \mathrm{C}$ in the dark during sedimentation. Microscope counts were made, within a week from sampling, in sedimentation chambers with an inverted Zeiss microscope equipped with phase contrast and epifluorescence. Generally, $100 \mathrm{ml}$ of original sample volume were scanned, but smaller and larger volumes were counted at very high or very low ciliate concentrations (range 25 to $250 \mathrm{ml}$ sample volume). Ciliates with fluorescent chloroplasts distributed all over the cell were considered mixotrophic.

For live observations, $1 \mathrm{l}$ was collected from the $-1 \mathrm{~m}$ Niskin bottle and surface net tows (mesh size $40 \mu \mathrm{m}$ ) were performed. The live Niskin bottle sample was concentrated by gravity filtration down to about $150 \mathrm{ml}$ and this concentrate, as well as the live net sample, was observed immediately upon arrival in the laboratory. Live ciliates were picked out under an Olympus Stereomicroscope, and both live and fixed specimens were observed with a Zeiss Axioskop, equipped with bright light and DIC objectives up to $63 \times$. Taxonomic determinations were possible most of the time to the genus level following Montagnes \& Lynn (1991). However, the parallel observations described above were of great help to distinguish between choreotrich morphotypes in the formalin-preserved samples. Biovolumes were calculated from linear measurements of each cell referring to simple geometric shapes, and biomass was calculated using a conversion factor of $0.14 \mu \mathrm{g} \mathrm{C}_{\mu \mathrm{m}}^{-3}$ for formalin-preserved ciliates (Putt \& Stoecker 1989).

Choreotrichs were divided into 3 size classes: small ciliates of $<30 \mu \mathrm{m}$ equivalent spherical diameter (ESD), medium-sized ciliates $>30$ and $<50 \mu \mathrm{m}$ ESD, and large ciliates $>50 \mu \mathrm{m}$ ESD. To calculate production, average biovolume for each sample, size class and trophic group was used. Choreotrich production was calculated from the multiple regression equations established by Perez et al. (1997) for maximum observed growth rates $(\mu)$ :

for mixotrophic choreotrichs:

$$
\ln \mu=1.4 \ln T-0.08 \ln V-3.22
$$

and for heterotrophic choreotrichs:

$$
\ln \mu=0.85 \ln T-0.08 \ln V-1.34
$$

where $T$ is temperature $\left({ }^{\circ} \mathrm{C}\right)$ and $V$ is cell volume $\left(\mu \mathrm{m}^{3}\right)$.

Production was calculated for the separate size classes as: $P=\mu \cdot$ Biomass.

Production of Mesodinium rubrum was calculated from the data presented by Stoecker et al. (1991). They reported an average carbon assimilation rate of $23.8 \mathrm{fg}$ $\mathrm{C} \mu \mathrm{m}^{-3} \mathrm{~h}^{-1}$ for $M$. rubrum at saturating light $(\geq 275 \mu \mathrm{E}$ $\mathrm{m}^{-2} \mathrm{~s}^{-1}$ ). Maximum potential production for M. rubrum for each sample was calculated as follows:

$$
P\left(\mu \mathrm{Cl}^{-1} \mathrm{~d}^{-1}\right)=N \times V \times 23.8 \times H \times 10^{-9}
$$

where $N=$ cells $1^{-1}, V=$ average volume $\left(\mu \mathrm{m}^{3}\right)$ and $H$ is daylength (h).

Annual production of choreotrichs and Mesodinium rubrum was calculated by averaging the values of 2 consecutive samplings for the days separating the samples, then adding all the daily production values.

Pearson's coefficient of correlation was calculated to test the relationship of different parameters measured, and abundance and calculated biomass of the ciliate assemblages. A Student's $t$-test was performed for differences in abundance and relative contributions of ciliate groups. A principal component analysis (PCA) (Lagonegro \& Feoli 1985) was performed on the matrix 'physical and biological data', containing temperature, salinity, differences in sigma $\mathrm{T}$ (i.e. differences in sea water density 0 to $70 \mathrm{~m}$ as an index of stratification of the water column), chlorophyll a concentrations and biomass of the different ciliate groups for the 3 yr study.

\section{RESULTS}

Stratification started in April and the pycnocline deepened during spring and summer, to eventually reach about $40 \mathrm{~m}$ depth in November, and then disappeared with a complete mixing of the water column with homothermic conditions prevailing until March. Temperature at the surface $(-2 \mathrm{~m})$ ranged from 13.3 to $28.6^{\circ} \mathrm{C}$; salinity values ranged between 36.9 and 38.1 ( $37.63 \pm 0.31, N=142)$. Highest chlorophyll $a$ concentrations were always observed in the first few meters, with a steep gradient with depth observed during the period of stratification. During mixed winter conditions the distribution of chlorophyll along the water column was more homogenous. Chlorophyll concentrations in the surface layer over the 3 years of this study varied between 0.14 and $7.45 \mu \mathrm{g} \mathrm{chl}^{-1}$ (Fig. 1a), with $60 \%$ of the samples having $<1 \mu \mathrm{g} \mathrm{chl} \mathrm{l}^{-1}$. Average values of chlorophyll concentrations differed for the periods of stratified and mixed water column, $1.71 \pm 1.46 \mu \mathrm{g} \mathrm{chl}$ $\mathrm{l}^{-1}$ for the periods April-October and $0.86 \pm 1.17 \mu \mathrm{g} \mathrm{chl}$ $\mathrm{l}^{-1}$ for the November-March periods $(t$-test $\mathrm{p}<0.002)$. The contribution of chlorophyll size fractions were $26 \%( \pm 19), 28 \%( \pm 20)$ and $45 \%( \pm 28)$ for the $<2,2$ to 10 and $>10 \mu \mathrm{m}$ chlorophyll fractions, respectively. The contribution of the $<2 \mu \mathrm{m}$ chlorophyll fraction was $22 \%$ during the periods of stratified water column and $30 \%$ during winter mixing. However, differences in the contribution of the 3 chlorophyll size fractions for stratified versus winter periods were not significant ( $t$-test, $\mathrm{p}>0.05)$. Increments in chlorophyll concentrations were associated with low surface salinity values, 

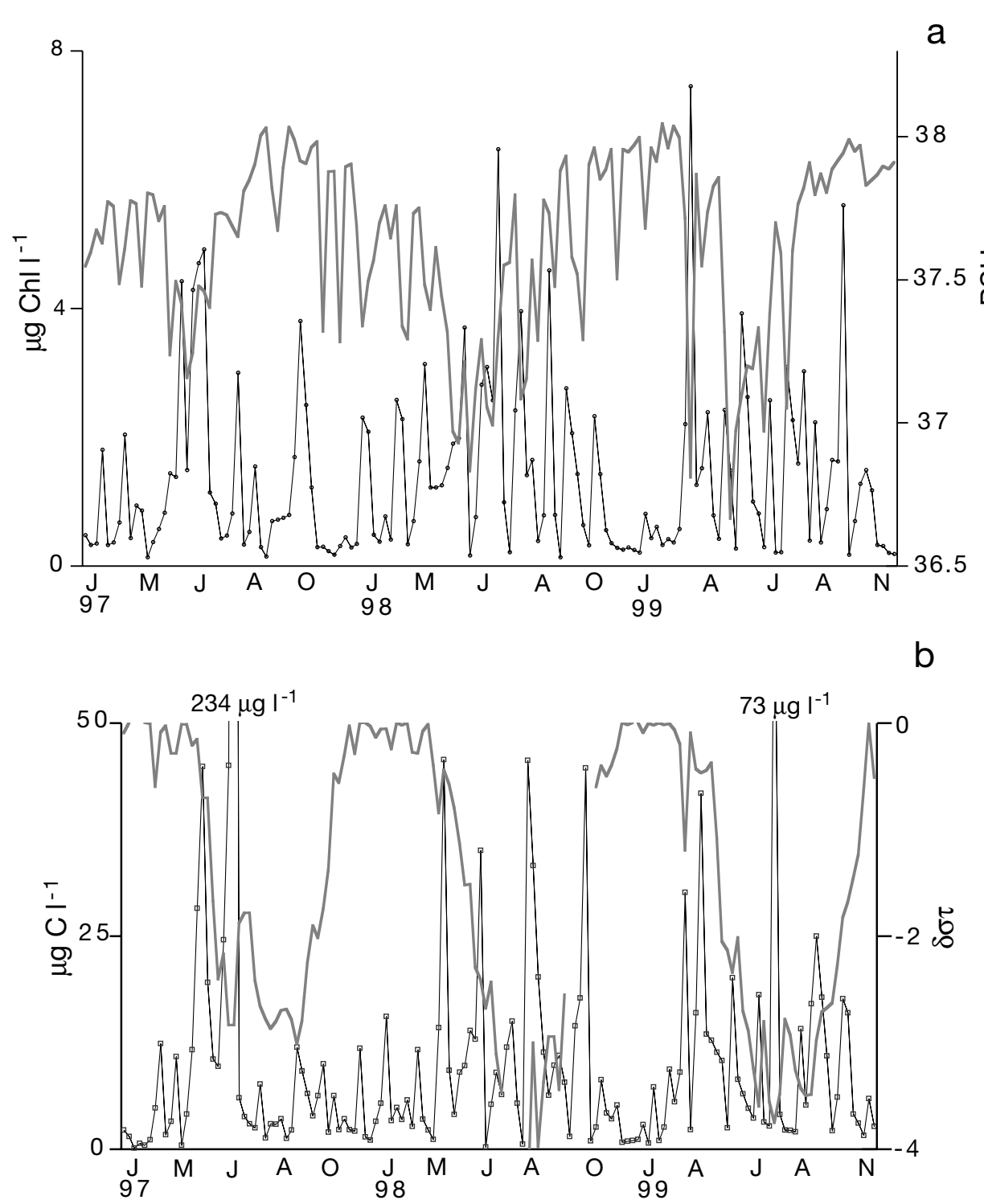

Fig. 1. (a) Variations in surface salinity values (gray line) and chlorophyll a concentrations ( $\left.\mu \mathrm{g} \mathrm{l}^{-1},-\circ\right)$ at Stn MC, 1997 to 1999. (b) Differences, 0 to $70 \mathrm{~m}$, in seawater density $\left(\delta \sigma \tau\right.$, gray line) and total ciliate biomass values ( $\left.\mu \mathrm{g} \mathrm{C}^{-1},-{ }^{-}\right)$at $\mathrm{Stn} \mathrm{MC}$, 1997 to 1999

observed mostly during the months of stable stratification of the water column (Fig. 1a). In fact, the pycnocline delimits the less saline coastal waters to the upper layer and coastal waters might expand out to Stn MC.

Highest values of ciliate abundance and biomass were observed during the periods of stratified water column (Fig. 1b). A significant negative correlation was found between salinity and chlorophyll concentrations $(\mathrm{r}=-0.36, \mathrm{p}<0.01, \mathrm{~N}=142)$ and between salinity and ciliate biomass and abundance (Mesodinium not included) $\mathrm{r}=-0.38$ and $\mathrm{r}=-0.34(\mathrm{p}<0.01$, $\mathrm{N}=142$ ), respectively. The occurrence of Mesodinium b

was not correlated to salinity values. A positive correlation between total chlorophyll concentrations and ciliate (again except Mesodinium) biomass $\mathrm{r}=0.428$ and abundance $\mathrm{r}=$ $0.41(\mathrm{p}<0.01, \mathrm{~N}=142)$ oc$\supset$ curred. A positive correlation, œ $\mathrm{p}<0.01$, was found between the $<2$ and the 2 to $10 \mu \mathrm{m}$ chlorophyll fractions and biomass of small- and mediumsized mixotrophic and of the $<30 \mu \mathrm{m}$ ESD heterotrophic choreotrichs (Table 1). Larger heterotrophic choreotrichs as well as the large mixotrophic ciliate Laboea strobila showed less or no correlation to these chlorophyll size fractions. The abundance of both heterotrophic and mixotrophic choreotrichs was positively correlated $(\mathrm{p}<0.01)$ to pico- and nanochlorophyll concentrations (Fig. 2).

The PCA applied to the matrix 'physical and biological data' yielded 3 significant axes accounting for 36.6, 15.8 and $12.6 \%$ of the system variance, for a total of $65 \%$. In the resulting ordination model (Fig. 3) 4 main clusters are recognized, with the opposition along F1 of salinity and the different groups of non-tintinnid ciliates; along F2 there is an opposition of temperature and differences in seawater density (DST 0 to 70) on one hand and Mesodinium rubrum and tintinnids on the other. The introduction of F3 did not alter the configuration except for the opposition along F3 of temperature and density differences.

Annual average abundance and biomass of the whole ciliate assemblage varied little between years, from $10.5 \mu \mathrm{g} \mathrm{Cl}^{-1}$ in 1999 to $11.8 \mu \mathrm{g} \mathrm{Cl}^{-1}$ in 1997. However, abundance and biomass of the ciliate population varied within very wide ranges, from 0.2 to $271 \times 10^{3}$ cells $\mathrm{l}^{-1}$ and 0.1 to $234 \mu \mathrm{g} \mathrm{C} \mathrm{l}^{-1}$, respectively (Table 2). Aloricate choreotrichs contributed $65 \pm 18 \%$ to total ciliate biomass and $62 \pm 16 \%$ to ciliate abundance, and among the choreotrichs $61 \%$ in terms of biomass and 
$44 \%$ of cell numbers were mixotrophic. Mesodinium rubrum contributed about $9 \%$ to ciliate abundance and biomass. Tintinnids were observed at abundances of $490 \pm 609$ tintinnids $\mathrm{l}^{-1}$ in $94 \%$ of the samples; peaks in tintinnid abundance were observed at high total ciliate abundance and biomass. The group 'other ciliates' of Table 2 and Figs. 3 \& 4 include all nonchoreotrichous ciliates. Small scuticociliates were by far the most abundant, while Hypotrichida, Pleurostomida and Prostomatida were mostly observed at low concentrations.

Photosynthetic ciliates showed pronounced seasonal variations in their relative contribution to ciliate biomass. Mixotrophic choreotrichs were most important during periods of stratified water column when they contributed up to $89 \%$ of total ciliate biomass. On the other hand, the maximum contribution of the auto-trophic Mesodinium rubrum occurred during winter when it provided on average $22 \%$ and up to $48 \%$ of total ciliate biomass (Fig. 4). A negative correlation was found between the relative contribution of these 2 compartments to total ciliate abundance $(\mathrm{r}=-0.376, \mathrm{p}<0.001)$ and biomass $(\mathrm{r}=-0.473, \mathrm{p}<0.001)$.

The autotrophic ciliate Mesodinium rubrum was observed in 124 of the 142 samples and was the single most frequently observed and abundant species in the Gulf of Naples. M. rubrum occurred in 2 forms: a larger (Meso1, 28 to $45 \mu \mathrm{m}$ cell length) and a smaller form (Meso2, 16 to $20 \mu \mathrm{m}$ length). Both types showed high concentrations in spring and autumn, the larger form reaching $164 \times 10^{3} \mathrm{cells}^{-1}$ on June 10 , 1997. The peak occurred immediately after a major mixing event due to stormy weather in May 1997, which partially eroded the seasonal stratification of the water column. No $M$. rubrum was observed the week after this peak on June 17, 1997, and the species was absent until August 1997. M. rubrum was represented almost exclusively by Meso1 in winter and by Meso2 in summer (Fig. 5). Average annual abundances for the 2 forms
Table 1. Pearson's correlation coefficients between total and size-fractioned chlorophyll concentration and biomass of ciliate groups; ${ }^{*} \mathrm{p}<0.05_{i}{ }^{* *} \mathrm{p}<0.01$

\begin{tabular}{|llrrl|}
\hline & $\begin{array}{l}\text { Chl total } \\
(\mathrm{N}=142)\end{array}$ & $\begin{array}{r}>10 \mu \mathrm{m} \\
(\mathrm{N}=58)\end{array}$ & $\begin{array}{r}2-10 \mu \mathrm{m} \\
(\mathrm{N}=58)\end{array}$ & $\begin{array}{l}<2 \mu \mathrm{m} \\
(\mathrm{N}=58)\end{array}$ \\
\hline Mixotrophic choreotrichs & & & & \\
Small, $<30 \mu \mathrm{m}$ & $0.384^{* *}$ & 0.156 & $0.544^{* *}$ & $0.581^{* *}$ \\
Medium-sized, 30 to $50 \mu \mathrm{m}$ & $0.325^{* *}$ & -0.141 & $0.450^{* *}$ & $0.406^{* *}$ \\
Large, $>50 \mu \mathrm{m}$ & $0.201^{*}$ & 0.010 & $0.361^{* *}$ & $0.305^{*}$ \\
All mixotrophs & $0.368^{* *}$ & 0.006 & $0.541^{* *}$ & $0.523^{* *}$ \\
Laboea strobila & 0 & -0.030 & $0.331^{* *}$ & 0.228 \\
Tontonia spp. & 0.144 & -0.182 & $0.270^{*}$ & $0.370^{* *}$ \\
Other Strombidiidae & $0.477^{* *}$ & -0.100 & $0.563^{* *}$ & $0.526^{* *}$ \\
Heterotrophic choreotrichs & & & & \\
Small, <30 $\mu \mathrm{m}$ & $0.366^{* *}$ & 0.132 & $0.581^{* *}$ & $0.455^{* *}$ \\
Medium-sized, 30 to 50 $\mu \mathrm{mm}$ & 0.148 & -0.122 & 0.065 & $0.327^{* *}$ \\
Large, $>50 \mu \mathrm{m}$ & $0.196^{*}$ & -0.182 & $0.302^{*}$ & 0.245 \\
All heterotrophs & $0.299^{* *}$ & -0.093 & $0.473^{* *}$ & $0.500^{* *}$ \\
Mesodinium rubrum & $0.220^{* *}$ & 0.248 & $0.491^{* *}$ & 0.226 \\
& & & & \\
\hline
\end{tabular}
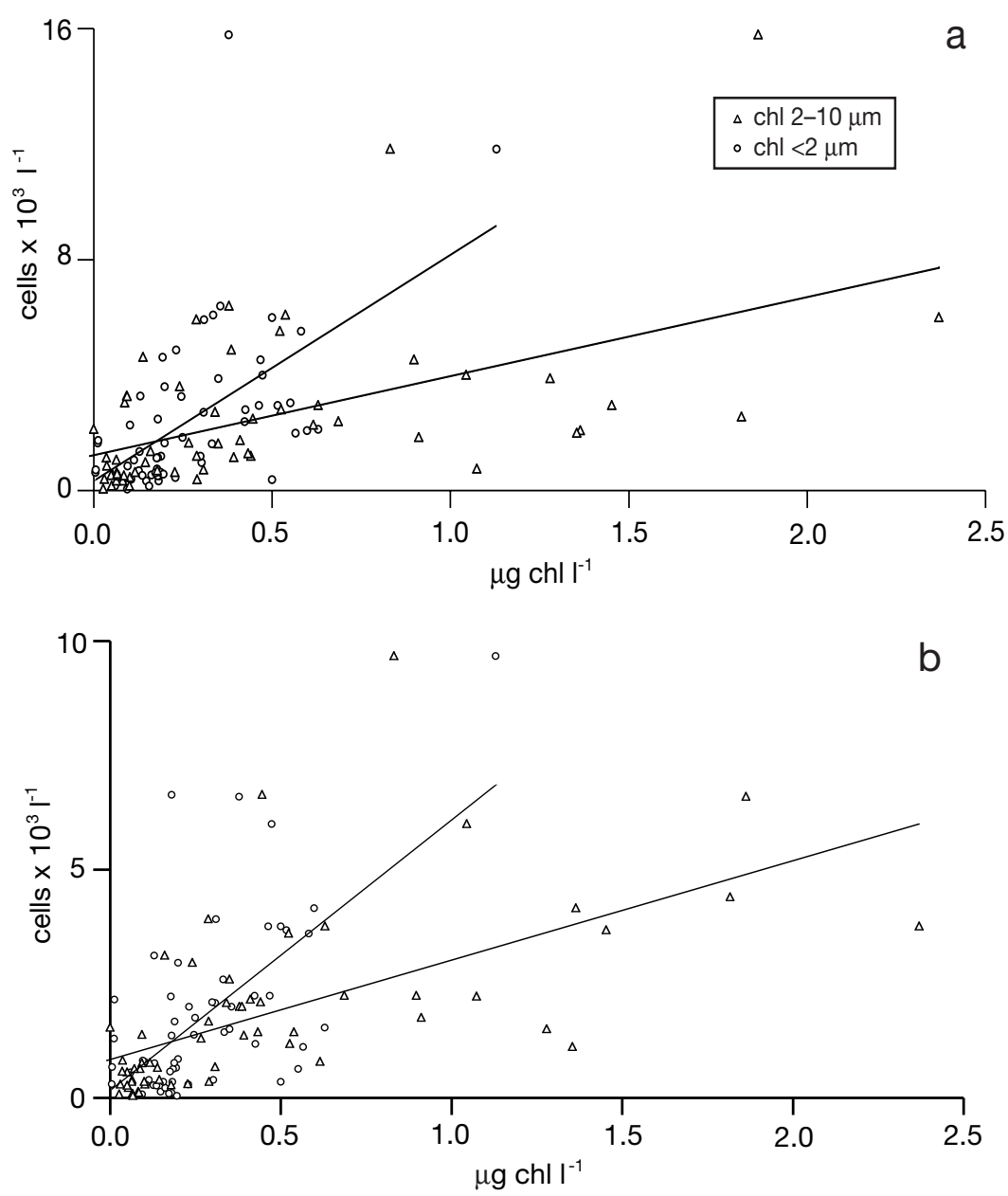

Fig. 2. Aloricate choreotrich abundance (cells $\left.\times 10^{3} \mathrm{l}^{-1}\right)$ at different concentrations of $<2 \mu \mathrm{m}(\mathrm{o})$ and $>2$ to $<10 \mu \mathrm{m}$ chlorophyll $(\Delta)$ size fractions. (a) Heterotrophic choreotrichs $\left(\mathrm{r}^{2}=0.31, \mathrm{p}<0.01\right.$ for $<2 \mu \mathrm{m} \mathrm{chl} ; \mathrm{r}^{2}=0.16, \mathrm{p}<0.01$ for 2 to $10 \mu \mathrm{m}$ chl). (b) Mixotrophic choreotrichs $\left(\mathrm{r}^{2}=0.38, \mathrm{p}<0.01\right.$ for $<2 \mu \mathrm{m} \mathrm{chl}$; $\mathrm{r}^{2}=0.25, \mathrm{p}<0.01$ for 2 to $\left.10 \mu \mathrm{m} \mathrm{chl}\right)$ 
Fig. 3. Ordination model performed by PCA technique on a matrix of 9 variables and 141 cases. SAL: salinity, DST-0-70: differences in seawater density (Sigma T), TEMP: temperature, TOTCHL: total chlorophyll concentrations; abbreviations for different ciliate groups

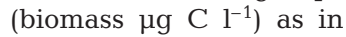
Table 2

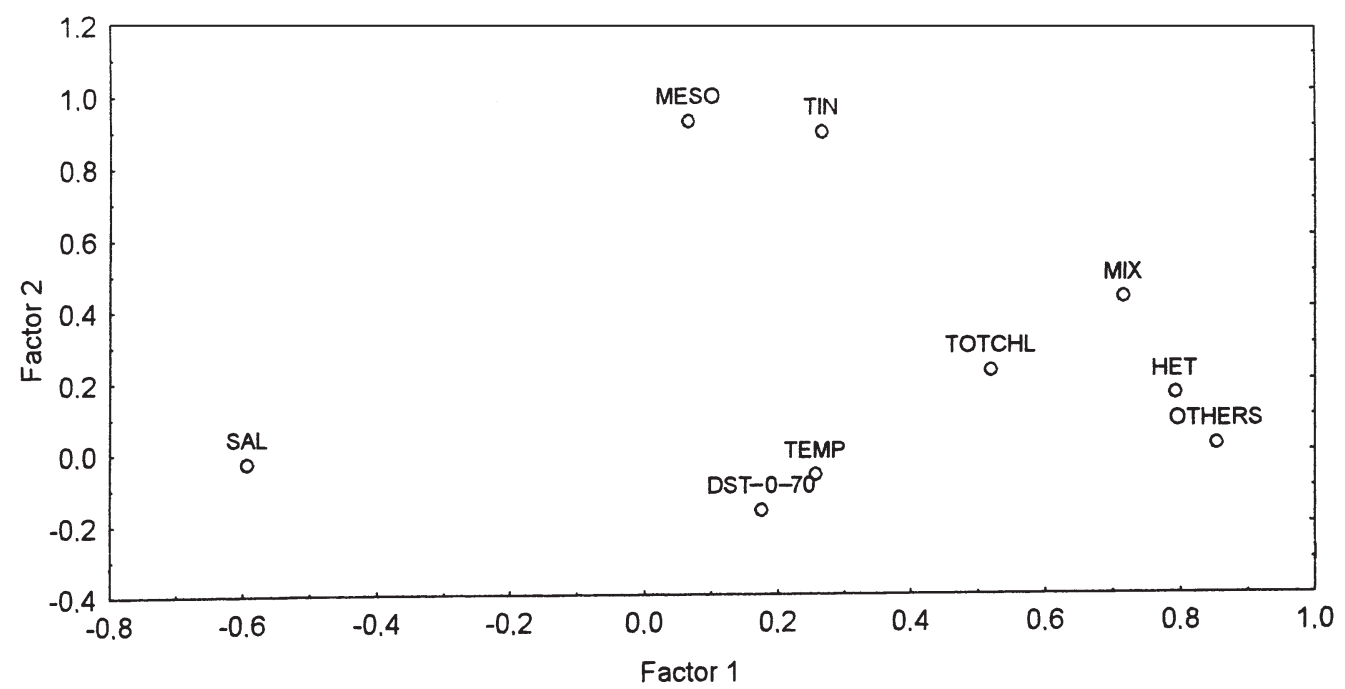

Table 2. Annual mean (range) for biomass ( $\mu \mathrm{g} \mathrm{C} \mathrm{l}^{-1}$ ) and abundance (cells $\times 10^{3} \mathrm{l}^{-1}$ ) of the ciliate assmeblage 1997 to 1999 . Aloricate choreotrichs: heterotrophs (Het); mixotrophs (Mix); Tintinnids (Tin); Mesodinium rubrum (Meso); Others: non choreotrichous ciliates

\begin{tabular}{|lclllll|}
\hline & Total & Mix & Het & Tin & Meso & Others \\
\hline Biomass & & & & & & \\
1997 & $11.8(0.1-234.0)$ & $3.2(0-24.1)$ & $1.7(0-12.9)$ & $2.4(0-50.0)$ & $3.4(0-135.0)$ & $0.8(0-13.9)$ \\
1998 & $10.7(0.3-45.7)$ & $4.0(0.1-28.9)$ & $3.0(0-19.8)$ & $2.1(0-21.7)$ & $0.7(0-7.5)$ & $0.9(0-5.0)$ \\
1999 & $10.5(0.7-72.8)$ & $4.6(0.2-25.6)$ & $2.8(0-32.1)$ & $1.6(0-17.2)$ & $0.4(0-4.8)$ & $1.1(0-12.3)$ \\
Abundance & & & & & & \\
1997 & $10.9(0.2-271.1)$ & $1.5(0-5.8)$ & $1.7(0-12.2)$ & $1.3(0-30.5)$ & $3.9(0-164.1)$ & $2.5(0-58.6)$ \\
1998 & $7.6(0.3-32.1)$ & $2.0(0-9.7)$ & $2.7(0-15.8)$ & $0.9(0-6.7)$ & $0.7(0-3.3)$ & $1.4(0-10.9)$ \\
1999 & $6.8(0.7-65.5)$ & $1.6(0-4.9)$ & $2.6(0.2-43.9)$ & $1.0(0-13.9)$ & $0.4(0-3.3)$ & $1.2(0-13.8)$ \\
\hline
\end{tabular}

were similar, if the single peak value of June 1997 for

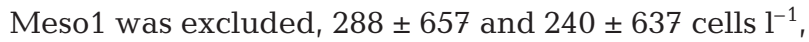
for the larger and the smaller form of $M$. rubrum, respectively.

Production of Mesodinium rubrum ranged from 0.3 to $0.5 \mathrm{~g} \mathrm{C} \mathrm{m}^{-3} \mathrm{yr}^{-1}$, when the peak value of June 1997 was excluded (Table 3). Production estimates are based on probable maximum rates (Stoecker et al.
1991) and light saturation was assumed as irradiance at the surface at Stn MC exceeds $275 \mu \mathrm{E} \mathrm{m} \mathrm{m}^{-2} \mathrm{~s}^{-1}$ year round (author's unpubl. data). The presence of $M$. rubrum was sporadic in summer, but during the months from November through March, i.e. the period of mixed water column, the larger form was observed at concentrations of $490 \pm 733$ cells $\mathrm{l}^{-1}$. The average daily production for this period ranged from 1.5 to

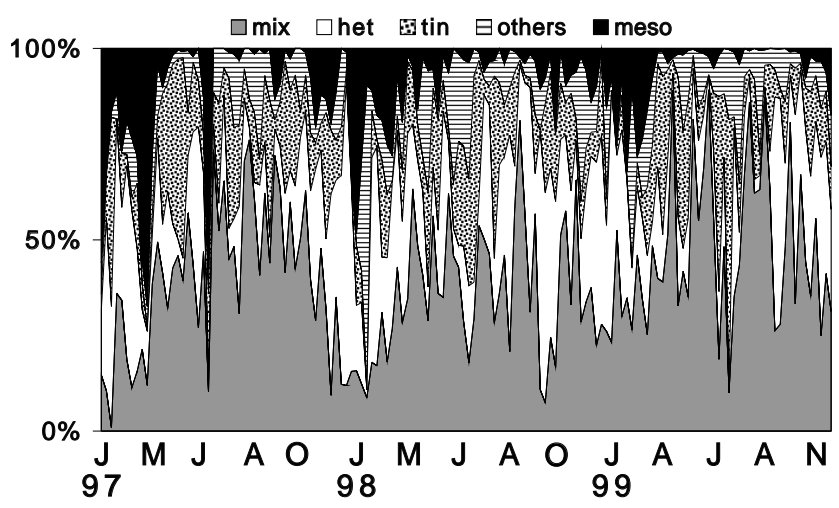

Fig. 4. Relative contribution to total ciliate biomass of the different ciliate trophic guilds at Stn MC, 1997 to 1999

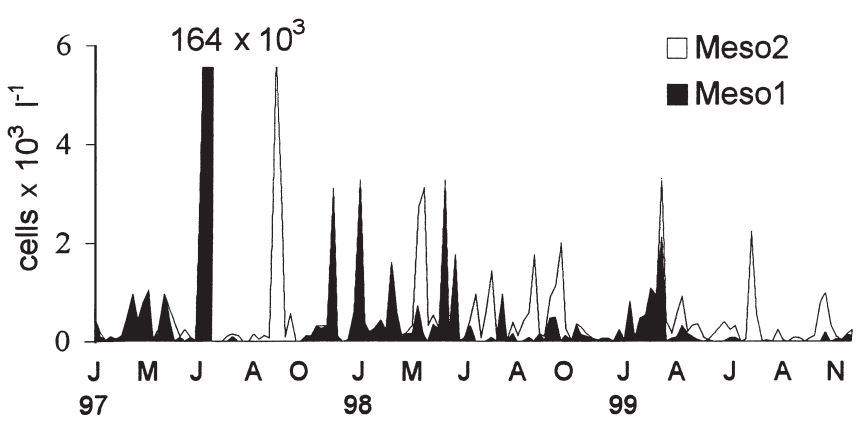

Fig. 5. Variations in abundance (cells $\times 10^{3} \mathrm{l}^{-1}$ ) of the 2 forms of Mesodinium rubrum at Stn MC, 1997 to 1999 
Table 3. Mesodinium rubrum. Estimated daily production $( \pm \mathrm{SD})$ for mixed and stratified water column and annual production at Stn MC 1997 to 1999

\begin{tabular}{|lrccc|}
\hline & Mixed & $\begin{array}{c}\text { Stratified } \\
\left(\mu \mathrm{g} \mathrm{C}^{-1} \mathrm{~d}^{-1}\right)\end{array}$ & Stratified & $\begin{array}{c}\text { Annual } \\
\left(\mathrm{g} \mathrm{C} \mathrm{m}^{-3} \mathrm{yr}^{-1}\right)\end{array}$ \\
\hline 1997 & $2.24 \pm 2.3$ & $12.5 \pm 59.4$ & $(0.64 \pm 2.5)^{\mathrm{a}}$ & $2.6(0.4)^{\mathrm{a}}$ \\
1998 & $1.8 \pm 2.7$ & $1.12 \pm(1.5)$ & & 0.5 \\
1999 & $1.5 \pm 2.3$ & $0.24 \pm(0.5)$ & 0.3 \\
\multicolumn{2}{|c|}{ axcept peak value of June 10, 1997 } \\
\hline
\end{tabular}

$2.2 \mu \mathrm{g} \mathrm{C} \mathrm{l}^{-1} \mathrm{~d}^{-1}$. Lower estimated production occurred during the periods of stratified water column, 0.24 to $1.12 \mu \mathrm{g} \mathrm{C}^{-1} \mathrm{~d}^{-1}$, when the single maximum of June 1997 was excluded (Table 3).

Plastidic choreotrichs made up an average of $40 \pm$ $19 \%$ of total ciliate biomass, and $27 \pm 15 \%$ of the abundance (Table 2). Large mixotrophs, such as Laboea strobila and Cyrtostrombidium sp. (as described by Agatha \& Riedel-Lorje 1997), showed high abundances, exceeding 1000 cells $\mathrm{l}^{-1}$ in early spring, MarchApril. Then a highly diversified assemblage of mixotrophic Strombidium was established and eventually remained until late autumn. Concentration of any single Strombidium morphotype generally did not exceed a few hundred cells per liter; most morphotypes were represented at very low concentrations. Tontonia spp. showed maximum abundances in late summer and in autumn, when $L$. strobila was absent, or occurred at very low concentrations. The same pattern of succession for the 3 mixotrophic genera was observed for each of the 3 years of this study (Fig. 6). Tontonia spp. and L. strobila contributed $19 \%$ to total mixotrophic ciliate abundances and $30 \%$ to biomass. The contribution of any single morphotype generally did not exceed 12 to $15 \%$ of total mixotroph abundances, particularly during the period of stratified water column. Peaks in mixotrophic choreotrich abundance and biomass were most commonly due to the increment of several morphotypes.

Medium-sized mixotrophs were reported in all but 10 of the 142 samples; however, the small, $<30 \mu \mathrm{m}$ cells contributed $72 \pm 18 \%$ to mixotrophic ciliate abundance (Fig. 7). Pooling the data for the periods of mixed and stratified water column for the 3 years of study, i.e. a total of 50 samples for the winter periods (November-March) and 92 samples for the stratified periods (April-October), a $t$-test was performed for differences in abundance and relative contribution of mixotrophic and heterotrophic choreotrich size classes. In winter, lower abundances of small- (mean 441 cells $\mathrm{l}^{-1}$ ) and

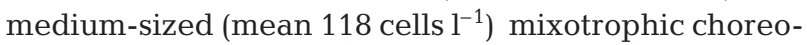
trichs were recorded, as compared to the mean abundances of these 2 size classes during the period of strat-
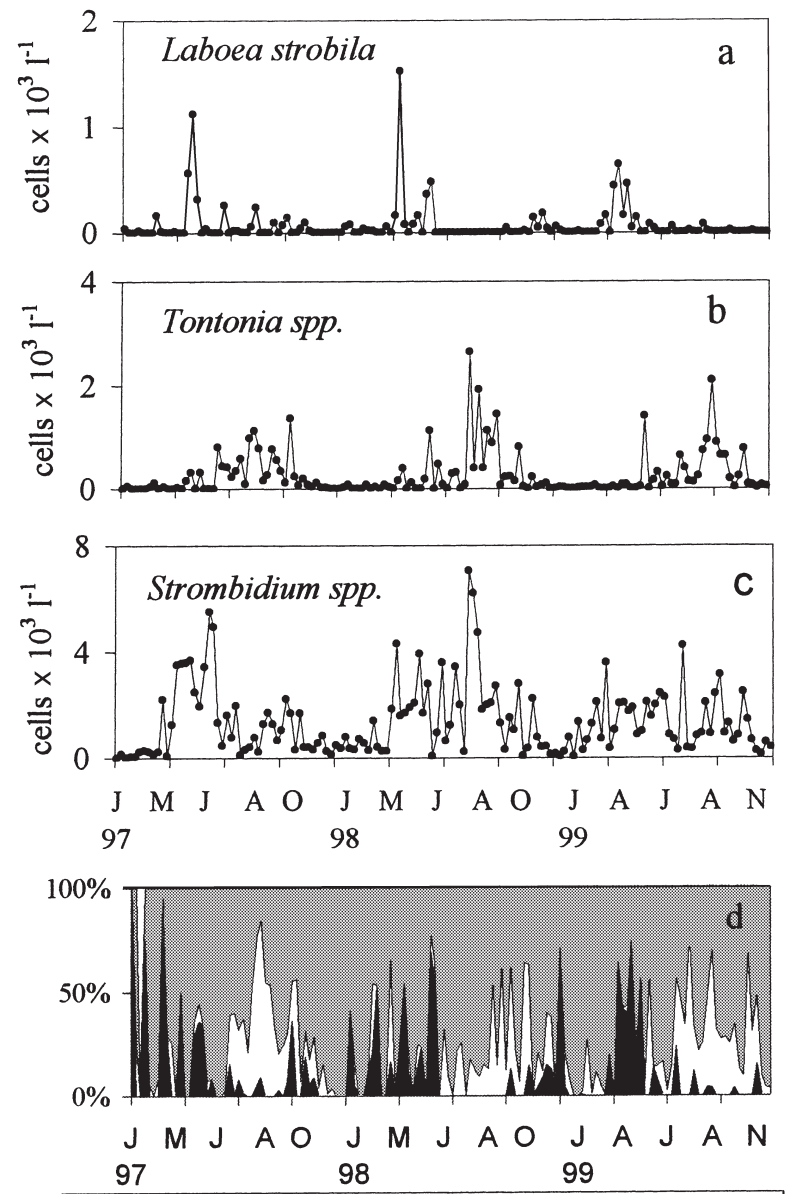

L. strobila $\square$ Tontonia spp. $\square$ Strombidium spp.

Fig. 6. Abundance (cells $\times 10^{3} \mathrm{l}^{-1}$ ) at Stn MC, 1997 to 1999 of (a) Laboea strobila, (b) Tontonia spp. (c) Strombidium spp. and (d) relative contribution (\%) to total mixotrophic choreotrich biomass of these 3 genera

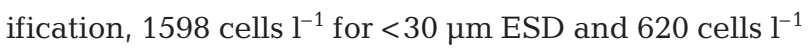
for 30 to $50 \mu \mathrm{m}$ ESD mixotrophs. Differences in abundance during the periods of mixed and stratified water column were significant ( $t$-test, $\mathrm{p}<0.001$ ). In contrast, relative contributions to mixotrophic ciliate abundance of the different size classes were similar ( $t$-test, $\mathrm{p}>0.5$ ) for the 2 periods, 71 to $74 \%$ were $<30 \mu \mathrm{m}$ cells, and 23 to $25 \%$ were medium-sized, 30 to $50 \mu \mathrm{m}$ cells (Table 4 ).

For heterotrophic choreotrichs, the dominance of $<30 \mu \mathrm{m}$ cells was even more pronounced, $92 \pm 9 \%$ of abundance, than that observed for the mixotrophic ciliates. Furthermore, $60 \pm 22 \%$ of all heterotrophic choreotrichs had a biovolume of $<3000 \mu^{3}$; average ESD for these nanociliates was $15.7 \mu \mathrm{m}$. For the mixotrophic ciliate compartment the contribution of cells with a volume of $<3000 \mu^{3}$ was $19 \pm 18 \%$ of total mixotrophic abundance. Medium-sized heterotrophic 

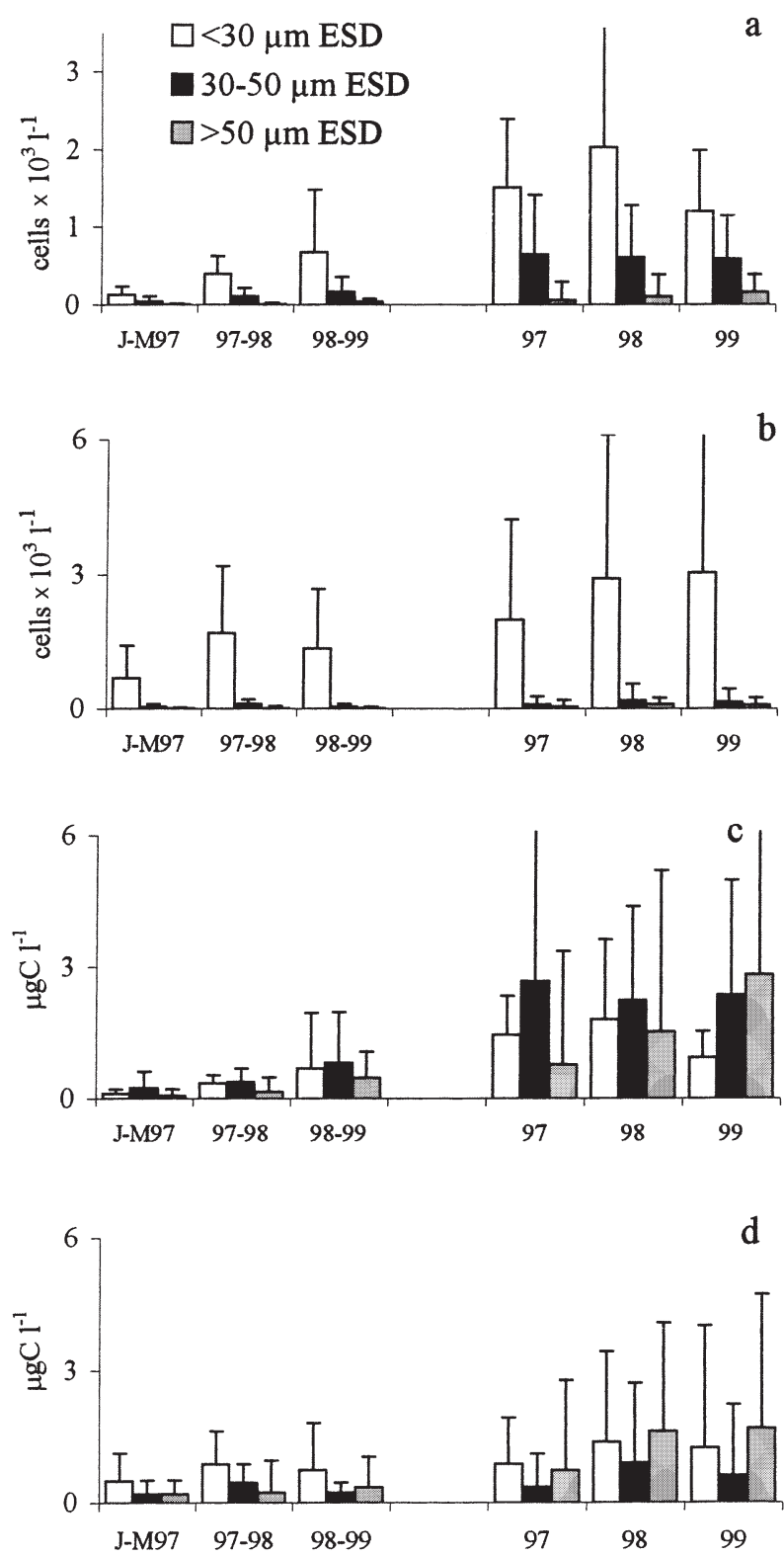

Fig. 7. Different size classes of aloricate choreotrichs during the periods of mixed water column (left part of each panel) and of stratified water column (right part of each panel), 1997 to 1999. Mean and standard error bars. Abundance (cells $\times$ $10^{3} \mathrm{l}^{-1}$ ) of (a) mixotrophic and (b) heterotrophic choreotrichs.

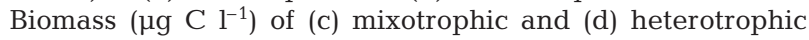
choreotrichs

choreotrichs were absent in 44 of the 142 samples, particularly in summer. Peaks in biomass of aloricate heterotrophs were mostly due to the increment of 1 morphotype, a single Strobilidium sp. reached 10000 cells $\mathrm{l}^{-1}$ on April 8,1998 . Significant differences in abundance of small $(<30 \mu \mathrm{m}$ ESD) heterotrophic choreotrichs occurred during periods of stratified water column and in winter $(t$-test, $\mathrm{p}=0.004)$. However, the relative contribution, 91 to $92 \%$, to total heterotrophic ciliate concentrations was similar for both seasons ( $t$-test, $\mathrm{p}=$ $0.56)$. Variations in abundance of medium-sized and large heterotrophic choreotrichs were very pronounced, and differences in abundance between the 2 seasons, as well as relative contribution of these 2 size classes, were less significant (Table 4). In summary, $<30 \mu \mathrm{m}$ cells were the most abundant for both trophic groups. Variations in percent contribution were minor and occurred sporadically for the $<30 \mu \mathrm{m}$ heterotrophs, while medium-sized mixotrophs often contributed to a greater extent to total mixotroph abundance in springsummer, although, as outlined above, the seasonal differences were found to be not significant.

The estimated annual production for each year of this study for heterotrophic and mixotrophic choreotrichs ranged from 0.88 to 1.55 and 1.42 to $1.86 \mathrm{~g} \mathrm{C} \mathrm{m}^{-3}$ $\mathrm{yr}^{-1}$. For mixotrophic choreotrichs, about half was due to the medium-sized, 30 to $50 \mu \mathrm{m}$ ESD cells, while for the heterotrophic choreotrichs approximately $50 \%$ of the production occurred for the small, $<30 \mu \mathrm{m}$ cells (Table 5).

\section{DISCUSSION}

Abundance and biomass values of the ciliate assemblage in the Gulf of Naples, although being within the range reported from different marine sites (Lynn \& Montagnes 1991, Pierce \& Turner 1992), were considerably higher than the records from the Mediterranean Sea. An average of $0.75 \mu \mathrm{g} \mathrm{Cl}^{-1}$ has been reported for open Mediterranean waters (Dolan et al. 1999) and the annual average of ciliate biomass, $11.0 \mu \mathrm{g} \mathrm{Cl}^{-1}$, in the Gulf of Naples was about twice the value reported in the Bay of Blanes (5.4 $\mathrm{g} \mathrm{C} \mathrm{C}^{-1}$, Vaque et al. 1997). The difference might have been even greater as the use of formol may give a loss of up to $65 \%$ of the naked choreotrichs (Stoecker et al. 1994a). However, tintinnids are not affected by the type of fixative used and $10.3 \%$ of loricate ciliates to total ciliate abundance found in the Gulf of Naples is close to what has been reported in other studies in the Mediterranean where Lugol was used (Vaque et al. 1997, Dolan et al. 1999). This suggests that major losses of the naked ciliates should not have occurred in this study.

The annual aloricate choreotrich production at Stn $\mathrm{MC}, 2.3$ to $3.4 \mathrm{~g} \mathrm{C} \mathrm{m}^{-3} \mathrm{yr}^{-1}$, was comparable to the values, 0.16 to $9.2 \mathrm{~g} \mathrm{C} \mathrm{m}^{-3} \mathrm{yr}^{-1}$, reported for the whole ciliate compartment, using regression equations based on maximum observed growth rates (Montagnes et al. 1988, Lynn \& Montagnes 1991, Leakey et al. 1992, Witek 1998 and references therein) or directly measuring the ciliate growth rates (Nielsen \& Kiørboe 1994). The relatively high annual average of ciliate 
Table 4. Abundance (cells $\times 10^{3} \mathrm{l}^{-1}$ ) and relative contribution (\%) of different size classes of mixotrophic (Mix) and heterotrophic (Het) choreotrichs. Pooled data 1997 to 1999 for winter $(N=52)$ and stratified $(N=90)$ water column. Student's $t$-test for differences between the 2 periods. ESD: equivalent spherical diameter

\begin{tabular}{|c|c|c|c|c|c|c|}
\hline \multirow[t]{2}{*}{ ESD } & \multicolumn{2}{|c|}{$<30 \mu \mathrm{m}$} & \multicolumn{2}{|c|}{$30-50 \mu \mathrm{m}$} & \multicolumn{2}{|c|}{$>50 \mu \mathrm{m}$} \\
\hline & Abundance & $\mathrm{p}$ & Abundance & $\mathrm{p}$ & Abundance & $\mathrm{p}$ \\
\hline \multicolumn{7}{|l|}{ Mix } \\
\hline Winter & $0.4(0.5)$ & 0.000 & $0.1(0.1)$ & 0.000 & $0.2(0.3)$ & 0.108 \\
\hline Stratified & $1.6(1.3)$ & & $0.6(0.7)$ & & $0.1(0.3)$ & \\
\hline \multicolumn{7}{|l|}{ Het } \\
\hline Winter & $1.3(1.3)$ & 0.004 & $0.1(0.1)$ & 0.435 & $0.02(0.04)$ & 0.027 \\
\hline \multirow[t]{2}{*}{ Stratified } & $2.7(4.8)$ & & $0.1(0.3)$ & & $0.1(0.2)$ & \\
\hline & $\%$ & $\mathrm{p}$ & $\%$ & $\mathrm{p}$ & $\%$ & $\mathrm{p}$ \\
\hline \multicolumn{7}{|l|}{ Mix } \\
\hline Winter & 74 (19) & 0.87 & 23 (19) & 0.578 & $4(6)$ & 0.066 \\
\hline Stratified & $71(17)$ & & $25(16)$ & & $4(7)$ & \\
\hline \multicolumn{7}{|l|}{ Het } \\
\hline Winter & $92(6)$ & 0.563 & $7(6)$ & 0.012 & $1(2)$ & 0.049 \\
\hline Stratified & 91 (11) & & $6(8)$ & & $3(5)$ & \\
\hline
\end{tabular}

biomass and annual production recorded in the Gulf of Naples may be explained by the occurrence of several peaks in chlorophyll and ciliate concentrations over approximately $8 \mathrm{mo} \mathrm{yr}^{-1}$ of stratified water column, as compared to a spring peak and a minor autumn peak in ciliate biomass reported for other temperate coastal sites.

Peaks in ciliate abundance occurred together with peaks in chlorophyll concentrations and were associated with mixing events during the onset of stratification, or with the expansion of low-salinity coastal waters to the study site. The response of the ciliate assemblage to eutrophication pulses has also been reported for other coastal areas (Coats \& Revelante 1999) and is evidenced by the ordination model (Fig. 3). Moreover, the central position of chlorophyll in the model suggests its dependence from both physical and biological parameters. The correlation coefficients between chlorophyll concentrations and biomass of ciliate groups indicate that the standing crops of phytoplankton and ciliates co-vary. The positive correlation encountered between several ciliate groups and their algal prey, in particular pico- and nanophytoplankton, suggests increments in abundance of both prey and predators to occur with an increase in resource availability, i.e. nutrient-rich coastal waters tracked by low salinity values. No lag time in the response of the ciliate assemblage to variations in salinity or chlorophyll concentrations could be found. A sampling interval of 1 wk was probably too long as major variations in ciliate abundance and biomass have been observed on a day-to-day basis at Stn MC (author's unpubl. data) and in the Ligurian Sea (Perez et al. 2000).
Table 5. Annual production (g $\left.\mathrm{C} \mathrm{m}^{-3} \mathrm{yr}^{-1}\right)$ at $\mathrm{Stn} \mathrm{MC}$ estimated from maximum observed growth rates (Perez et al. 1997) for mixotrophic (Mix) and heterotrophic (Het) choreotrich size classes

\begin{tabular}{|lcccc|}
\hline ESD & $<30 \mu \mathrm{m}$ & $30-50 \mu \mathrm{m}$ & $>50 \mu \mathrm{m}$ & All \\
\hline Mix & & & & \\
1997 & 0.48 & 0.75 & 0.20 & 1.42 \\
1998 & 0.68 & 0.74 & 0.39 & 1.80 \\
1999 & 0.39 & 0.75 & 0.71 & 1.86 \\
Het & & & & \\
1997 & 0.46 & 0.17 & 0.26 & 0.88 \\
1998 & 0.75 & 0.38 & 0.42 & 1.55 \\
1999 & 0.65 & 0.29 & 0.53 & 1.47 \\
\hline
\end{tabular}

The differences in correlation coefficients between ciliate groups and chlorophyll size fractions may be related to the different patterns of occurrence and grazing impact of the choreotrich groups. The alternation of mixotrophic genera during the year with large mixotrophs, such as Laboea strobila and Cyrtostrombidium sp., which showed peak abundances in different samples before a rich assemblage of plastidic Strombidium spp. was established, should reduce competition among the ciliates. The positive correlation between pico- and nanochlorophyll concentrations and biomass of all 3 mixotroph size classes may be explained by a more diversified grazing pressure, with several mixotrophic morphotypes occurring at low abundances. In contrast, peak abundances of $>30 \mu \mathrm{m}$ heterotrophic choreotrichs were often due to the increment of only 1 species and might be more likely to graze down the nanoplankton populations. 
Clearance rates of ciliates have been reported to be $10^{5}$ body volumes $\mathrm{h}^{-1}$, independent of ciliate body size (Neuer \& Cowles 1995). The calculated clearance rates of the $<30 \mu \mathrm{m}$ choreotrichs were on average only 2 to $4 \%$ of the water volume, and a positive correlation between pico- and nanophytoplankton and the ciliate compartment of mainly small cells has also been reported for other areas of the Mediterranean Sea (Bernard \& Rassoulzadegan 1994, Perez et al. 2000). On the other hand, for Laboea strobila, a clearance rate on cyanobacteria 8.8 times that of small naked choreotrichs has been reported (James et al. 1996). The lack of correlation between $<2 \mu \mathrm{m}$ chlorophyll concentrations and L. strobila abundance $(r=0.215, \mathrm{p}>0.1)$ and biomass $(r=0.228, p=0.1)$ might be explained by the heavy impact of this large choreotrich on the picoplankton populations.

The non-significant correlation between $>10 \mu \mathrm{m}$ chlorophyll concentrations and the different ciliate groups reported here suggests that variations in ciliate biomass were rather related to food availability than to an indirect effect of grazing release on the microzooplankton at high phytoplankton concentrations as has been hypothesized for other coastal sites (Smetacek 1981, Nielsen \& Kiørboe 1994).

Small aloricate cells dominated the ciliate population; in the Gulf of Naples $77 \%$ of the non-tintinnid ciliates were $<30 \mu \mathrm{m} \mathrm{ESD,} \mathrm{compared} \mathrm{to} 74 \%$ of $<30 \mu \mathrm{m}$ ciliates in the Northern Adriatic (Revelante \& Gilmartin 1983). Furthermore, nanociliates of $<18 \mu \mathrm{m}$ contributed $42 \%$ to total ciliate abundance in the Gulf of Naples compared to $44 \%$ in the Northern Aegean Sea and $28 \%$ in the extremely oligotrophic Southern Aegean Sea (Pitta \& Giannakourou 2000).

The relative contribution of nanociliates seems to decrease with oligotrophic conditions while the large mixotrophic genera Tontonia and Laboea achieve more importance in open Mediterranean waters (Dolan \& Marrasé 1995); their contribution to ciliate biomass has been observed to increase along a gradient of increasing oligotrophy (Dolan et al. 1999). Annual average biomass for Tontonia and Laboea was almost identical in the Gulf of Naples, $\left(1.2 \mu \mathrm{g} \mathrm{C}^{-1}\right)$ and in the Bay of Blanes (1.02 $\mu \mathrm{g} \mathrm{C}^{-1}$ ) (Vaque et al. 1997). However, in the Gulf of Naples the mixotrophic assemblage was mainly plastidic Strombidium spp. and, presumably, a considerable underestimation of the mixotrophic assemblage occurs when only Laboea and Tontonia are considered (Dolan \& Marrasé 1995, Vaque et al. 1997, Dolan et al. 1999).

Reports from a wide variety of marine sites for mixotrophic ciliate abundance and biomass give, in general, lower values than those observed in this study (overviews are presented in Stoecker 1991, Perez et al. 2000, Pitta \& Giannakourou 2000). The annual average of mixotrophic ciliate biomass is available for Great Harbor, $2.0 \pm 2.2 \mu \mathrm{g} \mathrm{C}{ }^{-1}$ (Stoecker et al. 1987). In particular, data on mixotroph abundance and biomass from the Mediterranean Sea are consistently lower than those reported here (Bernard \& Rassoulzadegan 1994, Perez et al. 2000, Pitta \& Giannakourou 2000, Table 6).

Bernard \& Rassoulzadegan (1994) carried out a 22 mo study of choreotrich ciliate populations at Villefranche, NW Mediterranean Sea; their data have been recalculated from ciliate biovolumes to carbon biomass, using

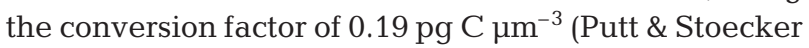
1989) for Lugol-preserved ciliates. An annual average of $1.14 \mu \mathrm{g} \mathrm{C}^{-1}$ and a maximum of $15.2 \mu \mathrm{g} \mathrm{Cl}^{-1}$ for the mixotrophic ciliate assemblage was reported at Villefranche, compared to $3.94 \mu \mathrm{g} \mathrm{C} \mathrm{l}^{-1}$ and up to $28.9 \mu \mathrm{g} \mathrm{C}$ $\mathrm{l}^{-1}$ for the Gulf of Naples. In both studies, about $50 \%$

Table 6. Mixotrophic ciliates at different sites in the Mediterranean Sea; abundance (cells $\mathrm{l}^{-1}$ ), biomass $\left(\mu \mathrm{g} \mathrm{C} \mathrm{l}^{-1}\right)$ and contribution (\%) of mixotrophic choreotrichs (All) and of only Tontonia and Laboea (TL) to total ciliate biomass

\begin{tabular}{|c|c|c|c|c|c|c|}
\hline Site & Period & Depth (m) & $\begin{array}{l}\text { Abundance } \\
\left(\text { cells } 1^{-1}\right)\end{array}$ & $\begin{array}{c}\text { Biomass } \\
\left(\mu \mathrm{C} \mathrm{C}^{-1}\right)\end{array}$ & $\%$ biomass & Source \\
\hline \multicolumn{7}{|l|}{ All } \\
\hline Villefranche & $22 \mathrm{mo}$ & 0 & & $1.14^{\mathrm{a}}$ & $51^{\mathrm{b}}$ & Bernard \& Rassoulzadegan (1994) \\
\hline Ligurian Sea & May & $5-50$ & 1120 & 0.59 & 39 & Perez et al. (2000) \\
\hline N Aegean Sea & Mar & $0-20$ & $30-1280$ & & $18-93$ & Pitta \& Giannakourou (2000) \\
\hline S Aegean Sea & Mar & $0-20$ & $70-210$ & & $5-89$ & Pitta \& Giannakourou (2000) \\
\hline Gulf of Naples & $3 \mathrm{yr}$ & 1 & 1686 & 3.94 & $40\left(61^{\mathrm{b}}\right)$ & This study \\
\hline \multicolumn{7}{|l|}{ TL } \\
\hline Catalan Sea & June & $0-20$ & & & 48 & Dolan \& Marrasé (1995) \\
\hline Blanes Bay & $3 \mathrm{yr}$ & 0.5 & 417 & 1.02 & 19 & Vaque et al. (1997) \\
\hline Tyrrhennian Sea & May-Jun & $0-80$ & & & 22 & Dolan et al. (1999) \\
\hline Levatine Basin & May-Jun & $0-80$ & & & 30 & Dolan et al. (1999) \\
\hline Gulf of Naples & $3 \mathrm{yr}$ & 1 & 321 & 1.20 & 12 & This study \\
\hline
\end{tabular}


of choreotrich biomass of each size class were mixotrophic ciliates, except for medium-sized choreotrichs in the Gulf of Naples for which $71 \%$ of biomass was mixotrophs. Another study taking into account the different size classes of mixotrophic ciliates was carried out in the Aegean Sea (Pitta \& Giannakourou 2000). Small <18 $\mu \mathrm{m}$ ESD mixotrophic cells were the most abundant under the extremely oligotrophic conditions prevailing in this area. However, at stations in the Northern Aegean Sea, which receives low salinity waters from the Black Sea, the mixotrophic ciliate assemblage in the surface layer was dominated by mediumsized mixotrophs. The success of mixotrophic ciliates in the Gulf of Naples might be related to their ability to survive in conditions of low prey levels, and in this

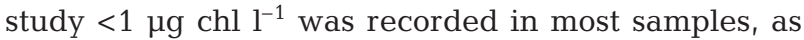
they may profit from both phagotrophy and photosynthesis (Dolan 1992). In addition, high biomasses were recorded for the mixotrophic assemblage, related to the influence of coastal waters. From a comparison of the contribution of mixotrophs to the different choreotrich size classes (Bernard \& Rassoulzadegan 1994, this study), it seems that the medium-sized mixotrophs in particular gain more importance in response to environmental enrichment in the Gulf of Naples, as observed also in the Aegean Sea at stations influenced by Black Sea waters (Pitta \& Giannakourou 2000).

Photosynthesis in Mesodinium rubrum has been shown to vary with nutrient limitation, cell volume and light (Smith \& Barber 1979, Stoecker et al. 1991). Furthermore, disintegration of this very delicate ciliate may occur in formol-preserved samples (Crawford 1989). The occurrence of this species was probably underestimated due to loss of material in the formolpreserved samples (Lindholm et al. 1988) while, on the other hand, an overestimation was presumably also the case as production was calculated using maximum photosynthetic rates (Stoecker et al. 1991). Consequently, the contribution of $M$. rubrum to primary production presented here can only be considered as a very rough estimate. Primary production for the surface layer at Stn $\mathrm{MC}$ has been recorded to vary between 11.7 and $15.9 \mathrm{~g}$ $\mathrm{C} \mathrm{m}^{-3} \mathrm{yr}^{-1}$, with minimum values generally well below $10 \mathrm{mg} \mathrm{C} \mathrm{m}^{-3} \mathrm{~d}^{-1}$ in winter (Scotto di Carlo et al. 1985, Modigh et al. 1996, Saggiomo unpubl. data). M. rubrum contribute around $3 \%$ of annual primary production but possibly $20 \%$ or more of daily production in winter (Table 3). The complete mixing of the water column during winter is adverse for several phytoplankters but M. rubrum is still able to maintain a position favorable for photosynthesis in turbulent waters (Stoecker et al. 1989, Crawford \& Purdie 1992) and, in this study, the larger form was recorded in all samples during winter. In the Mediterranean in summer, the occurrence of only the smaller form of $M$. rubrum (Bernard \& Ras- soulzadegan 1994, this study) may be related to low nutrient availability and nutrient depletion has been invoked for the sudden disappearance of $M$. rubrum peaks (Smith \& Barber 1979, Stoecker et al. 1991, Nielsen \& Kiørboe 1994) as occurred in June 1997 at Stn MC.

Photosynthetic ciliates represent $49 \%$ of ciliate biomass in the Gulf of Naples. A minor part is entirely autotrophic, while the mixotrophic assemblage obtains about $37 \%$ (Jonsson 1987, Stoecker et al. 1988) or maybe over 50\% (Jonsson 1987, Stoecker \& Michaels 1991) of its energy demand from photosynthesis. A consistent part $(42 \%)$ of the aloricate choreotrichs had a biovolume $<3000 \mu^{3}$, reported to feed almost exclusively on bacteria and picoplankton (Sherr et al. 1986, 1989). Moreover, most of the other aloricate choreotrichs were small- $(<30 \mu \mathrm{m}$ ESD) or medium-sized (30 to $50 \mu \mathrm{m}$ ESD) cells, which have been observed to take 72 and $30 \%$, respectively, of picoplankton in their diet (Rassoulzadegan et al. 1988). Thus, the ciliate assemblage mostly depends on resources not available to mesozooplankton. An attempt was made to estimate the amount of ciliate production based upon grazing on bacteria and picoplankton in the proportions as outlined above and considering mixotrophic choreotrichs to obtain $37 \%$ of their carbon demand by photosynthesis. The ciliate production derived from such 'alternative' resources, i.e. photosynthesis and microbial prey, would be 1.2 to $1.6 \mathrm{mg} \mathrm{C}^{-1} \mathrm{l}^{-1} \mathrm{yr}^{-1}$, or about $50 \%$ of annual ciliate production. Ciliate consumption of bacteria and picoplankton, assuming 30\% assimilation efficiency, would amount to an average of $10 \mu \mathrm{g} \mathrm{C}^{-1} \mathrm{~d}^{-1}$. This estimate should be compared to the amount of grazed picoplankton production for Stn MC, which has been evaluated to be on average $158.2 \mathrm{mg} \mathrm{C} \mathrm{m}^{-2} \mathrm{~d}^{-1}$ (Modigh et al. 1996), and about $12 \mu \mathrm{g} \mathrm{C}^{-1} \mathrm{~d}^{-1}$ for the surface layer. However, data on bacterioplankton production are unfortunately not available for the Gulf of Naples.

Succession of the 2 forms of Mesodinium rubrum and of the different genera of mixotrophic Strombidiidae followed a predictable annual pattern for each of the 3 years of study. The photosynthetic ciliate assemblage was mainly represented by large mixotrophs, such as Laboea strobila, and by the large form (about $40 \mu \mathrm{m}$ length) of Mesodinium rubrum in winter, and in summer by a variety of mixotrophic Strombidium. In winter and summer, phytoplankton populations at Stn MC are mostly small, <10 um cells (Zingone \& Sarno 2000). During such periods, when the concentration of suitable algal foods is low, photosynthetic ciliates may be a readily available food resource of feasible size for larger zooplankters which rely on high quality $\geq 15$ to $20 \mu \mathrm{m}$ food particles (Stoecker et al. 1989). However, the observation of fairly stable ratios between the dif- 
ferent choreotrich size classes at any level of ciliate abundance indicates a grazing control by predators being able to grow at similar rates as their ciliate prey, i.e. 'protozoan controlling protozoan' (Paffenhöfer 1998). This denotes that the fate of photosynthetic ciliates in marine ecosystems has yet to be clarified.

Acknowledgements. I am grateful to Dr V. Zupo for help with statistical analysis and to Mr F. Corato for CTD profiles and chlorophyll analysis and for discussing his unpublished time series at Stn MC of inorganic nutrient concentrations. Moreover, thanks are due to my colleagues, Drs A. Ianora, M. G. Mazzocchi, V. Saggiomo and M. Ribera d'Alcalà, and to 4 anonymous reviewers for helpful criticism on a previous version of this manuscript.

\section{LITERATURE CITED}

Agatha S, Riedel-Lorje JC (1997) Morphology, infraciliature and ecology of Halteriids and Strombidiids (Ciliophora, Oligotrichea) from coastal brackish water basins. Arch Protistenkd 148:445-459

Banse K (1995) Zooplankton: pivotal role in the control of ocean production. I. Biomass and production measurements. ICES J Mar Sci 52:265-277

Bernard C, Rassoulzadegan F (1994) Seasonal variations of mixotrophic ciliates in the northwest Mediterranean Sea. Mar Ecol Prog Ser 108:295-301

Carrada GC, Hopkins TS, Bonaduce G, Ianora A, Marino D, Modigh M, Ribera d'Alcalà M, Scotto di Carlo B (1980) Variability in the hydrographic and biological features of the Gulf of Naples. PSZN I: Mar Ecol 1:105-120

Coats WD, Revelante N (1999) Distributions and trophic implications of microzooplankton. Ecosystems at the landsea margin: drainage basin to coastal sea. Coast Estuar Stud 55:207-239

Crawford DW (1989) Mesodinium rubrum: the phytoplankter that wasn't. Mar Ecol Prog Ser 58:161-174

Crawford DW, Purdie DA (1992) Evidence for avoidance of flushing from an estuary by a planktonic, phototrophic ciliate. Mar Ecol Prog Ser 79:259-265

Dolan JR (1992) Mixotrophy in ciliates: a review of chlorella symbiosis and chloroplast retention. Mar Microb Food Webs 6:115-132

Dolan JR, Marrasé C (1995) Planktonic ciliate distribution relative to a deep chlorophyll maximum: Catalan Sea, NW Mediterranean, June 1993. Deep-Sea Res 42:1965-1987

Dolan JR, Vidussi F, Claustre H (1999) Planktonic ciliates in the Mediterranean Sea: longitudinal trends. Deep-Sea Res 46:2025-2039

James MR, Hall JA, Barrett PD (1996) Grazing by protozoa in marine coastal and oceanic ecosystems off New Zealand. NZ J Mar Freshw Res 30:313-324

Jonsson PR (1987) Photosynthetic assimilation of inorganic carbon in marine oligotrich ciliates (Ciliophora, Oligotrichina). Mar Microb Food Webs 2:55-68

Lagonegro M, Feoli E (1985) Analisi multivariata di dati. Libreria Goliardica, Trieste

Laval-Peuto M, Rassoulzadegan F (1988) Autofluorescence of marine planktonic Oligotrichina and other ciliates. Hydrobiologia 159:99-110

Leakey RJG, Burkill PH, Sleigh MA (1992) Planktonic ciliates in Southampton Water: abundance, biomass, production, and role in pelagic carbon flow. Mar Biol 114:67-83

Lindholm T (1985) Mesodinium rubrum - a unique photosyn- thetic ciliate. Adv Aquat Microbiol 3:1-48

Lindholm T, Lindroos P, Mörk AC (1988) Ultrastructure of the photosynthetic ciliate Mesodinium rubrum. BioSystems 21:141-149

Lynn DH, Montagnes DJS (1991) Global production of heterotrophic marine planktonic ciliates. In: Reid PC, Turley CM, Burkill PH (eds) Protozoa and their role in marine processes. NATO ASI Series G25:281-307

Mazzocchi MG, Ribera d'Alcalà M (1995) Recurrent patterns in zooplankton structure and succession in a variable coastal environment. ICES J Mar Sci 52:679-691

McManus GB, Fuhrman JA (1986) Photosynthetic pigments in the ciliate Laboea strobila from Long Island Sound, USA. J Plankton Res 8:317-327

Modigh M, Ribera d'Alcalà M, Saggiomo V, Forlani G, Tosti E (1985) Time relationship between physicochemical and biological properties of phytoplankton blooms in the inner part of the Gulf of Naples, Summer 1983. Rapp Comm Int Mer Medit 29:109-110

Modigh M, Saggiomo V, Ribera d'Alcalà M (1996) Conservative features of picoplankton in a Mediterranean eutrophic area, the Bay of Naples. J Plankton Res 18:87-95

Montagnes DJS, Lynn DH (1991) Taxonomy of Choreotrichs, the major marine planktonic ciliates, with emphasis on the aloricate forms. Mar Microb Food Webs 5:59-74

Montagnes DJS, Lynn DH, Roff JC, Taylor WD (1988) The annual cycle of heterotrophic planktonic ciliates in the waters surrounding the Isles of Shoals, Gulf of Maine: an assessment of their trophic role. Mar Biol 99:21-30

Neuer S, Cowles TJ (1995) Comparative size-specific grazing rates in field populations of ciliates and dinoflagellates. Mar Ecol Prog Ser 125:259-267

Neveux J, Panouse M (1987) Spectrofluorometric determination of chlorophylls and phaeophytins. Archiv Hydrobiol 109:567-581

Nielsen TG, Kiørboe T (1994) Regulation of zooplankton biomass and production in a temperate, coastal ecosystem. 2 . Ciliates. Limnol Oceanogr 39:508-519

Paffenhöfer GA (1998) Heterotrophic protozoa and small metazoa: feeding rates and prey-consumer interactions. J Plankton Res 20:121-133

Perez M, Dolan JR, Fukai E (1997) Planktonic oligotrich ciliates in the NW Mediterranean: growth rates and consumption by copepods. Mar Ecol Prog Ser 155:89-101

Perez MT, Dolan JR, Vidussi F, Fukai E (2000) Diel vertical distribution of planktonic ciliates within the surface layer of the NW Mediterranean (May 1995). Deep-Sea Res 47 : 479-503

Pierce RW, Turner JT (1992) Ecology of planktonic ciliates in marine food webs. Rev Aquat Sci 6:139-181

Pitta P, Giannakourou A (2000) Planktonic ciliates in the oligotrophic Eastern Mediterranean: vertical, spatial distribution and mixotrophy. Mar Ecol Prog Ser 194:269-282

Putt M (1990) Abundance, chlorophyll content and photosynthetic rates of ciliates in the Nordic Seas during summer. Deep-Sea Res 37:1713-1731

Putt M, Stoecker DK (1989) An experimentally determined carbon volume ratio for marine 'oligotrichous' ciliates from estuarine and coastal waters. Limnol Oceanogr 34: $1097-1103$

Rassoulzadegan F, Laval Peuto M, Sheldon RW (1988) Partitioning of the food ration of marine ciliates between picoand nanoplankton. Hydrobiologia 159:75-88

Revelante N, Gilmartin M (1983) Microzooplankton distribution in the Northern Adriatic Sea with emphasis on the relative abundance of ciliated protozoan. Oceanol Acta 6: $407-415$ 
Revelante N, Gilmartin M (1987) Seasonal cycle of the ciliated protozoan and micrometazoan biomass in a Gulf of Maine Estuary. Estuar Coast Shelf Sci 25:581-598

Scotto di Carlo B, Tomas CR, Ianora A, Marino D, Modigh M, Mazzocchi MG, Montresor M, Petrillo L, Ribera D, d'Alcalà M, Saggiomo V, Zingone A (1985) Uno studio integrato dell'ecosistema pelagico costiero del Golfo di Napoli. Nova Thalassia 7:99-128

Sherr EB, Sherr BF, Paffenhöfer GA (1986) Phagotrophic protozoa as food for metazoans: a 'missing' trophic link in marine pelagic food webs? Mar Microb Food Webs 1:61-80

Sherr EB, Rassoulzadegan F, Sherr BF (1989) Bacterivory by pelagic choreotrichous ciliates in coastal waters of the NW Mediterranean Sea. Mar Ecol Prog Ser 55:235-240

Smetacek V (1981) The annual cycle of protozooplankton in the Kiel Bight. Mar Biol 63:1-11

Smith WOJ, Barber RT (1979) A carbon budget for the autotrophic ciliate Mesodinium rubrum. J Phycol 15: 27-33

Stoecker DK (1991) Mixotrophy in marine planktonic ciliates: physiological and ecological aspects of plastid-retention by oligotrichs. In: Reid PC, Turley CM, Burkill PH (eds) Protozoa and their role in marine processes. NATO ASI Series G25:161-179

Stoecker DK, Michaels AE (1991) Respiration, photosynthesis and carbon metabolism in planktonic ciliates. Mar Biol 108:441-447

Stoecker DK, Michaels AE, Davis LH (1987) Large proportion of marine planktonic ciliates found to contain functional chloroplasts. Nature 326:790-792

Stoecker DK, Silver MW, Michaels AE, Davis LH (1988) Obligate mixotrophy in Laboea strobila, a ciliate which retain chloroplasts. Mar Biol 99:415-423

Stoecker DK, Taniguchi A, Michaels AE (1989) Abundance of autotrophic, mixotrophic and heterotrophic planktonic cil-

Editorial responsibility: Fereidoun Rassoulzadegan, Villefranche-sur-Mer, France iates in shelf and slope waters. Mar Ecol Prog Ser 50: $241-254$

Stoecker DK, Putt M, Davis LH, Michaels AE (1991) Photosynthesis in Mesodinium rubrum: species-specific measurements and comparison to community rates. Mar Ecol Prog Ser 73:245-252

Stoecker DK, Gifford D, Putt M (1994a) Preservation of marine planktonic ciliates: losses and cell shrinkage during fixation. Mar Ecol Prog Ser 110:293-299

Stoecker DK, Sieracki ME, Verity PG, Michaels AE, Haugen E, Burkill PH, Edwards ES (1994b) Nanoplankton and protozoan microzooplankton during the JGOFS North Atlantic bloom experiment: 1989 and 1990. J Mar Biol Assoc UK 74:427-443

Stoecker DK, Gustafson DE, Verity PG (1996) Micro- and mesoprotozooplankton at $140^{\circ} \mathrm{W}$ in the equatorial Pacific: heterotrophs and mixotrophs. Aquat Microb Ecol 10: 273-282

Suzuki T, Yamada N, Taniguchi A (1998) Standing crops of planktonic ciliates and nanoplankton in oceanic waters of the western Pacific. Aquat Microb Ecol 14:49-58

Vaque D, Blough HA, Duarte CM (1997) Dynamics of ciliate abundance, biomass and community composition in an oligotrophic coastal environment (NW Mediterranean). Aquat Microb Ecol 12:71-83

Verity PG (1991) Measurement and simulation of prey uptake by marine planktonic ciliates fed plastidic and aplastidic nanoplankton. Limnol Oceanogr 36:729-750

Witek M (1998) Annual changes of abundance and biomass of planktonic ciliates in the Gdansk Basin, Southern Baltic. Int Rev Hydrobiol 83:163-182

Zingone A, Sarno D (2001) Recurrent patterns in coastal phytoplankton from the Gulf of Naples. Arch Oceanogr Limnol (in press)

Submitted: June 6, 2000; Accepted: November 8, 2000 Proofs received from author(s): January 24, 2001 